2005-01-01

\title{
Micro Shot Blasting of Machine Tools for Improving Surface Finish and Reducing Cutting Forces in Manufacturing
}

James Vahey

Technological University Dublin

David Kennedy

Technological University Dublin, david.kennedy@tudublin.ie

Follow this and additional works at: https://arrow.tudublin.ie/engschmecart

Part of the Mechanical Engineering Commons

\section{Recommended Citation}

Vahey, J., Kennedy, D.:Micro Shot Blasting of Machine Tools for Improving Surface Finish and Reducing Cutting Forces in Manufacturing. Materials \& Design, Vol. 26, 2005, p.203-208. doi:10.1016/

j.matdes.2004.02.013

This Article is brought to you for free and open access by the School of Mechanical and Design Engineering at ARROW@TU Dublin. It has been accepted for inclusion in Articles by an authorized administrator of ARROW@TU Dublin. For more information, please contact arrow.admin@tudublin.ie, aisling.coyne@tudublin.ie, gerard.connolly@tudublin.ie.

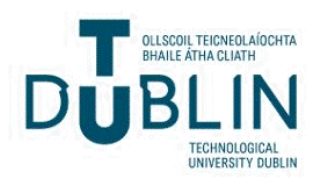




\title{
Micro shot blasting of machine tools for improving surface finish and reducing cutting forces in manufacturing
}

\author{
J. Vahey and D. Kennedy. \\ Dublin Institute of Technology, \\ Bolton Street, \\ Dublin 1.
}

Published by Materials \& Design, 26 (2005) 203-208

\begin{abstract}
Micro blasting of cutting tips and tools is a very effective and reliable method of advancing the life of tools under the action of turning, milling, drilling, punching and cutting. This paper outlines the ways in which micro blasted tools, both coated and un coated have benefited from shot blasting and resulted in greater productivity, lower cutting forces, improved surface finish of the work pieces and less machine downtime. The process of micro blasting is discussed in the paper. Its effectiveness depends on many parameters including the shot media ad size, the mechanics of impact and the application of the shot via the micro shot blasting unit. Control of the process to provide repeatability and reliability in the shot blasting unit is discussed. Comparisons between treated and untreated cutting tools are made and results of tool life for these cutting tips outlined. The process has shown to be of major benefit to tool life improvement as outlined in the paper.
\end{abstract}

Keywords: Micro Shot Blasting, surface finish, machine tools.

\section{Introduction}

Many modern techniques have been developed to enhance the life of components in service such as alloying additions, heat treatment, surface engineering, surface coating, implantation process, laser treatment and surface shape design. Processes such as thin film technology, plasma spraying, vacuum techniques depositing a range of multi-layered coatings have greatly enhanced the life, use and applications of engineering components and machine tools. Bombardment of components with millions of micro-shot ranging in size from $4 \mu \mathrm{m}$ to $50 \mu \mathrm{m}$ with a controlled process can lead to dramatic operating life improvements of such components. Standard shot peening was first used in an production process to extend the life of valve springs for Buick and Cadillac engines in the early 1930's [1,2] but prior to this it was a well known process used by blacksmiths and sword makers over time to improve the 
toughness of the cutting edges of their weapons. Cutting tips and tools can be greatly improved by the process of Micro Shot Blasting their surfaces to induce compressive residual stresses. The operating life of tools such as drills, turning tips, milling tips, punches, knife edges, slicers, blades, and a range of other working parts can benefit from this process.

Other components such as springs, dies, shafts, cams, and dynamic components in machines and engines can be enhanced by this process. Fatigue life of compressor components treated by shot peening have increased dramatically as reported by Eckersley and Ferrelli [3].

Other factors such as improved fatigue resistance, micro-crack closure, reduced corrosion and an improved surface finish can also be designed into components as a result of this process.

Not only can an improvement be made to the surface finish of the cutting tips and tools but also the surface finish of the work pieces machined with these tools have improved as a result of this technique.

Engineering materials such as tools steels, carbides, ceramics, coated carbides, through to polymers and rubbers can benefit from this process.

The key requirement for this process is to develop an automated micro-blasting process to fit inside a spray booth or standard shot blasting booth.

Shot material, size and mass, operating pressures, operating velocities, kinetic energy, density and coverage time will need to be perfected and optimised for a range of materials. The process is a line of sight method and can be applied to complex shapes such as the tips of drill bits.

\section{Method of operation}

One of the primary ways that components fail in service is through fatigue. This is closely associated with cyclic stresses and accelerated by tensile stresses, micro crack propagation and stress corrosion cracking. Cracks reduce the cross section of a material and eventually it will fail to support the loading applied. One simple method of reducing failure by fatigue is to arrest these tensile stresses by inducing compressive stresses into a surface. The benefits obtained with shot peening is a direct result of the residual compressive stresses produced in a component. A typical shot striking a surface is shown in Figure 1. Any applied tensile loads would have to 
overcome the residual compressive stresses before a crack could initiate according to Almen [4].

Poor machining of materials can result in residual stresses accruing at the surface. Rough surfaces have deeper notches, where cracks can initiate due to tensile stress concentrations at these points.

Many standard machining processes such as grinding, milling, turning, and coating processes such as electroplating induce residual tensile stresses in surfaces and this can lead to early failure of components treated by these processes. Further tensile loading in service would lead to early failure of this can be prevented by shot peening and micro blasting of component surfaces.

Micro shot blasting will change the following properties of a materials surface:

i. Resistance to fatigue fracture

ii. Resistance to stress corrosion

iii. A change in residual stresses

iv. Modification of surface finish

It is a cold working process involving bombarding powders such as ceramics, glass and metals of mainly spherical shapes against surfaces and can be used in conjunction with other processes. The main stages involved in this dynamic process include elastic recovery of the substrate after impact, some plastic deformation of the substrate if the impact pressure exceeds the yield stress, increased plastic deformation due to an increase in pressure and finally some rebound of the indenter due to a release of elastic energy. Some critical design characteristics of the micro shot peening process include the shot size, shape, hardness, density, durability, angle of impact, velocity and intensity. All of these parameters will influence the residual compressive stresses produced in the substrate.

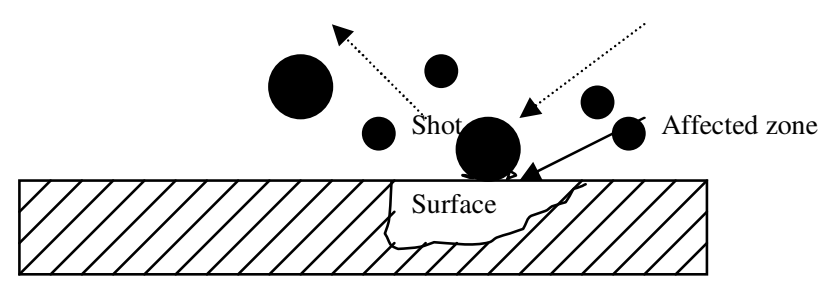

Figure 1. Shot peening process. 


\section{Experimental work}

Tool materials such as Tungsten Carbide, High Speed Steels used in milling and turning tools were subjected to the micro blasting process using different shot media (ceramic and glass bead) and shot size. Tests prior to and following the blasting process were conducted to ascertain any improvements resulting from the process. The micro-shot peening unit is shown in Photograph 1. It incorporates an air filter, pressure regulator and gauge, air flow regulator, pressurized blast media container and a venturi blast nozzle for directing the stream of micro shot. The unit is PLC controlled and a stepper motor, used to drive a lead screw is used to move the blast nozzle across the sample in order to control media shot coverage. The blast nozzle can also be rotated to allow the shot media to strike the samples at different angles. Tests undertaken include surface finish and roughness, machining tests on standard lathes and mills, hardness tests, cutting forces on turning operations, tool wear and the surface finish of the work pieces machined. Figures 2. and 3. show a typical High Speed Steel tip prior to and following the micro shot peening process using ceramic bead at a pressure of 5.5 Bar.

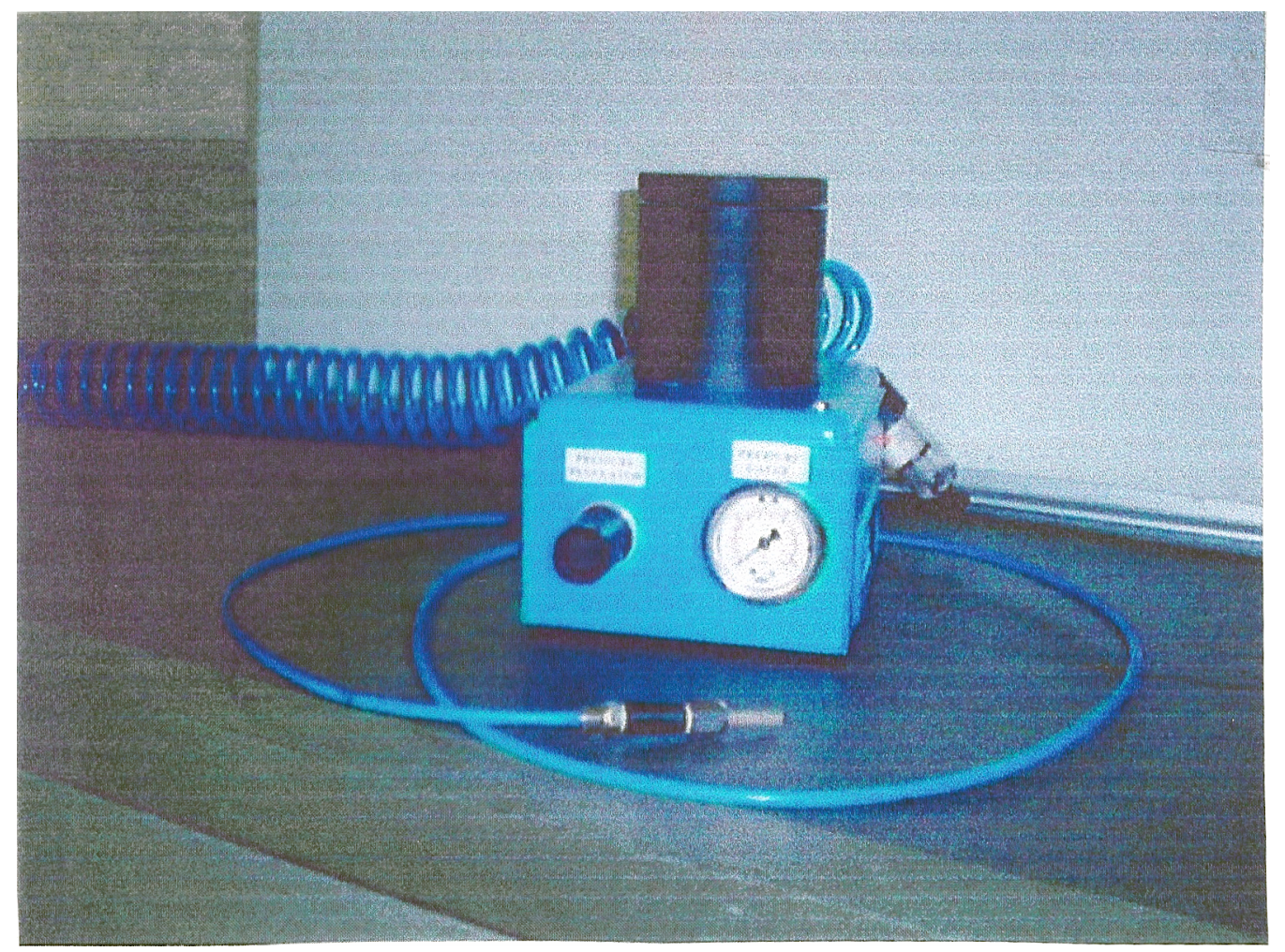

Photograph 1. Micro shot peening unit 


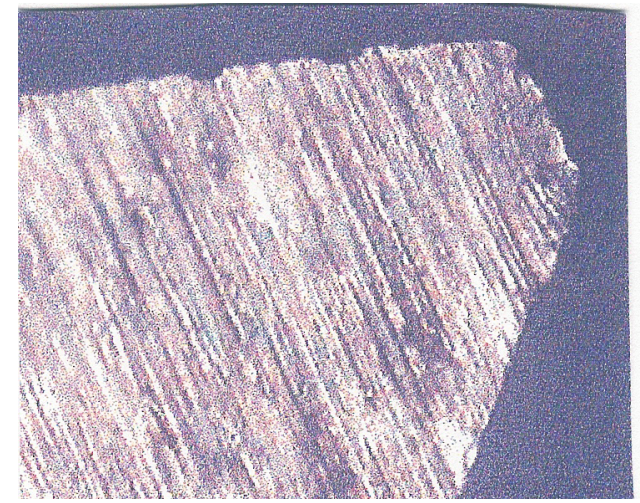

Figure 2. High Speed Steel Tip Prior to Treatment.

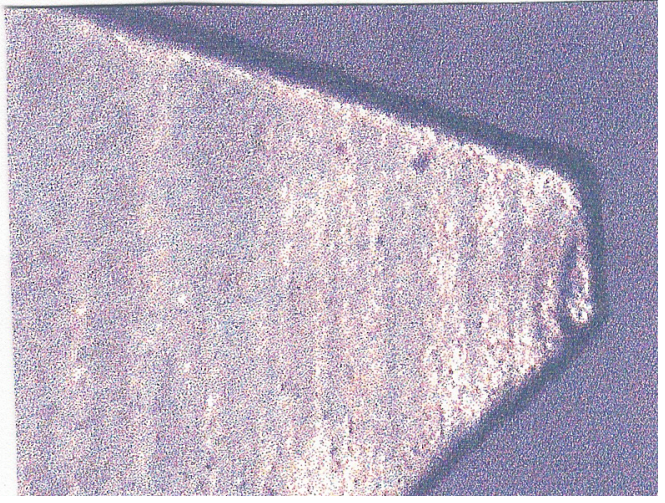

Figure 3. High Speed Steel Tip post treatment.

\section{Experimental results}

Testing of treated and untreated cutting tips and tools was conducted on High Speed Steels for turning and milling as well as coated and uncoated carbide inserts. A dynamometer was used to measure cutting forces on the turning tool (Lathe). The cutting process consisted of a depth of cut of $2 \mathrm{~mm}$ on a standard Bright Mild Steel specimen over a length of $750 \mathrm{~mm}$ while milling tests consisted of machining a $25 \mathrm{~mm} * 25 \mathrm{~mm} * 150 \mathrm{~mm}$ piece of mild steel using a depth of cut of $1 \mathrm{~mm}$ with a slot milling cutter of $18 \mathrm{~mm}$ diameter. Surface roughness measurements were conducted on the machined components prior to and after machining to establish whether the treated cutting tips performed any better than the untreated tips. Micro Hardness testing was also carried out to establish if there was any increase in surface hardness due to the micro shot peening process.

The impact angle of the shot was set at $90^{\circ}$ as this should give the optimum compressive layer [5]. The shot velocity on impact with a surface is largely dependent on the nozzle size, the air pressure and the distance from the substrate. The exposure time was adequate to give sufficient coverage of the substrate and this was determined by the Almen strip Saturation time, work piece indentation time and visual appearance. Harder materials such as carbides will obviously require longer exposure time or harder shot media.

The micro peening media used was a ceramic bead of approximately $40 \mu \mathrm{m}$ diameter providing high impact strength and hardness (NF L 06-824, approximately $60 \mathrm{HR}_{\mathrm{c}}$ ). 
Micro-Hardness tests

Combined Vickers Micro Hardness tests gave the results in Table 1. for both treated and untreated High Speed Steel (HSS)cutting tips.

\begin{tabular}{|l|c|}
\hline \multicolumn{1}{|c|}{ Sample } & $\mathrm{MH} \mathrm{v}(1000 \mathrm{~g})$ \\
\hline Untreated High Speed Steel & 936 \\
Treated High Speed Steel & 963 \\
Untreated Carbide tip & 1318 \\
Treated Carbide tip & 1388 \\
\hline
\end{tabular}

Table 1. Vickers Micro Hardness values

\section{Surface Roughness Values}

In all surface roughness tests conducted, the micro-blasted surface gave an improved surface roughness value. Surface roughness and profile tests were carried out on both a Talyor Hobson Tallysurf instrument and a non contact surface profileometer.

Surface roughness details of a typical untreated High Speed Steel cutting tip and a treated one are shown in Figures 4. and 5. and Table 2. shows the results of surface measurement values for other cutting tips and tools and workpieces.
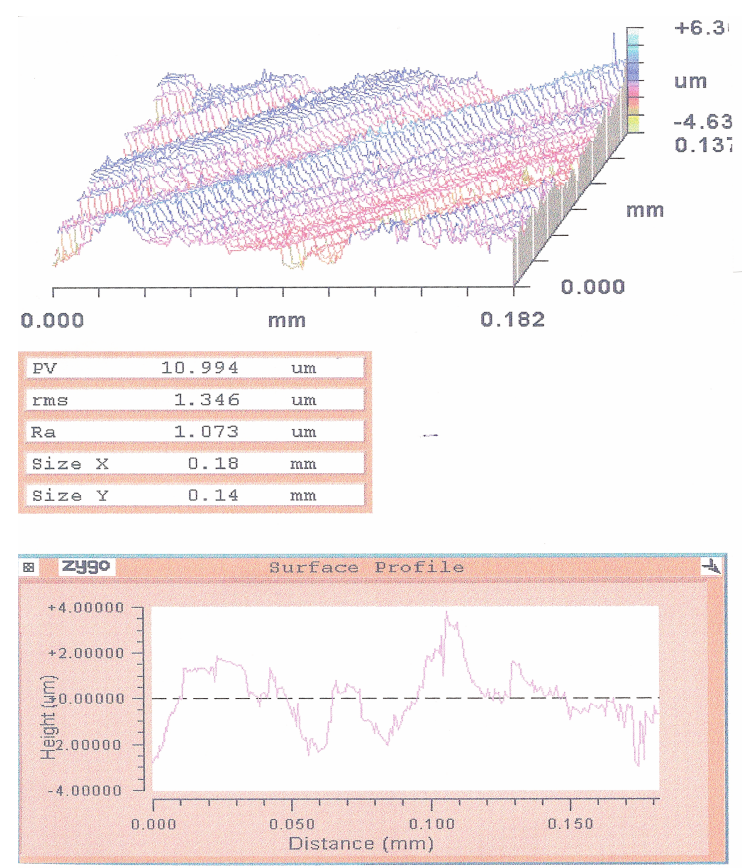

Figure 4. Surface values for untreated HSS. 

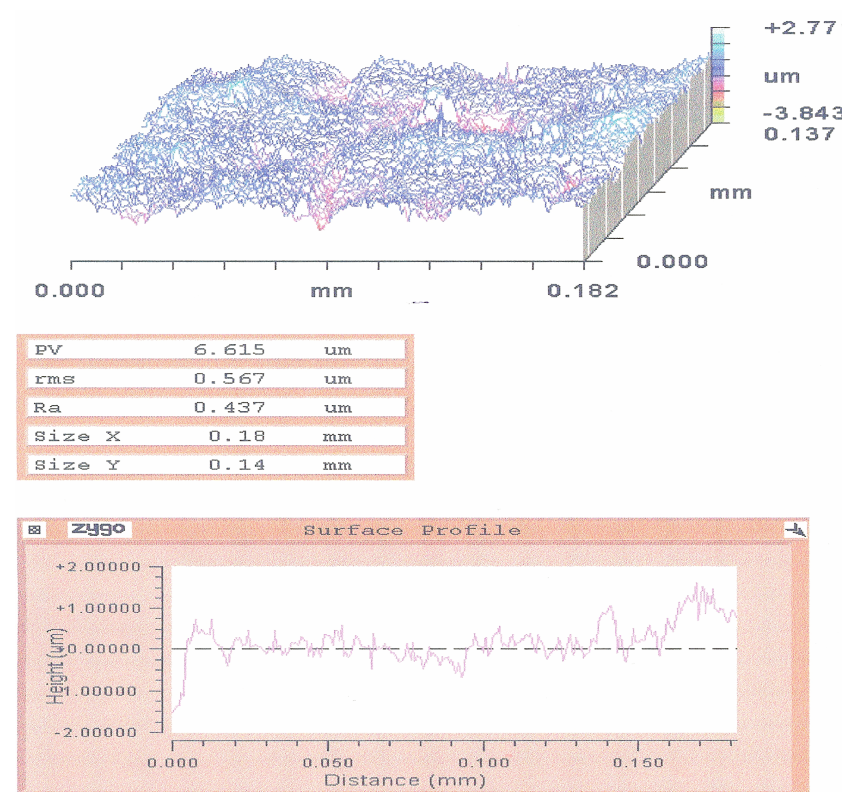

Figure 5. Surface values for treated HSS

\begin{tabular}{|c|c|c|c|}
\hline Sample & Treated/Untreated & Ra Value & Test method \\
\hline $\begin{array}{l}\text { Milled surface } \\
\text { carbide tool. } 225 \text { s cutting }\end{array}$ & Untreated & 2.2 & Tallysurf \\
\hline $\begin{array}{l}\text { Milled surface } \\
\text { carbide tool. } 225 \text { s cutting }\end{array}$ & Treated & 1.8 & Tallysurf \\
\hline $\begin{array}{l}\text { Milled surface HSS } \\
\text { 450s cutting }\end{array}$ & Untreated & 5.4 & Tallysurf \\
\hline $\begin{array}{l}\text { Milled surface HSS } \\
\text { after } 450 \text { s cutting. }\end{array}$ & Treated & 4.9 & Tallysurf \\
\hline $\begin{array}{l}\text { Turned surface } \\
\text { uncoated carbide } \\
\text { tip after } 30 \text { s cutting }\end{array}$ & Untreated & 3.0 & Tallysurf \\
\hline $\begin{array}{l}\text { Turned surface } \\
\text { uncoated carbide } \\
\text { tip after } 30 \text { s cutting }\end{array}$ & Treated & 2.7 & Tallysurf \\
\hline $\begin{array}{l}\text { Turned surface } \\
\text { coated carbide } \\
\text { tip after } 30 \text { s cutting }\end{array}$ & Untreated & 2.8 & Tallysurf \\
\hline $\begin{array}{l}\text { Turned surface } \\
\text { coated carbide } \\
\text { tip after } 30 \text { s cutting }\end{array}$ & Treated & 2.5 & Tallysurf \\
\hline $\begin{array}{l}\text { Turned surface } \\
\text { coated carbide } \\
\text { tip after } 2535 \text { s cutting }\end{array}$ & Untreated & 6.2 & Tallysurf \\
\hline $\begin{array}{l}\text { Turned surface } \\
\text { coated carbide } \\
\text { tip after } 2535 \text { s cutting }\end{array}$ & Treated & 3.8 & Tallysurf \\
\hline $\begin{array}{l}\text { Turned surface } \\
\text { HSS. } 2568 \mathrm{~s} \text { cutting }\end{array}$ & Untreated & 6.0 & Tallysurf \\
\hline $\begin{array}{l}\text { Turned surface } \\
\text { HSS. 2568s cutting }\end{array}$ & Treated & 4.7 & Tallysurf \\
\hline Drilled surface & Untreated & 2.2 & Profileometer \\
\hline Drilled surface & Treated & 1.024 & Profileometer \\
\hline
\end{tabular}

Table 2. $R_{a}$ values for work pieces. 
Figure 6. shows an uncoated carbide cutting tip which was not subjected to micro blasting. The flank wear was measured using an optical microscope and the value recorded was $150 \mu \mathrm{m}$ after 676 seconds of machining. Figure 7 . shows an uncoated carbide tip subjected to micro blasting. The flank wear in this case is only $90 \mu \mathrm{m}$ for the same machining time.

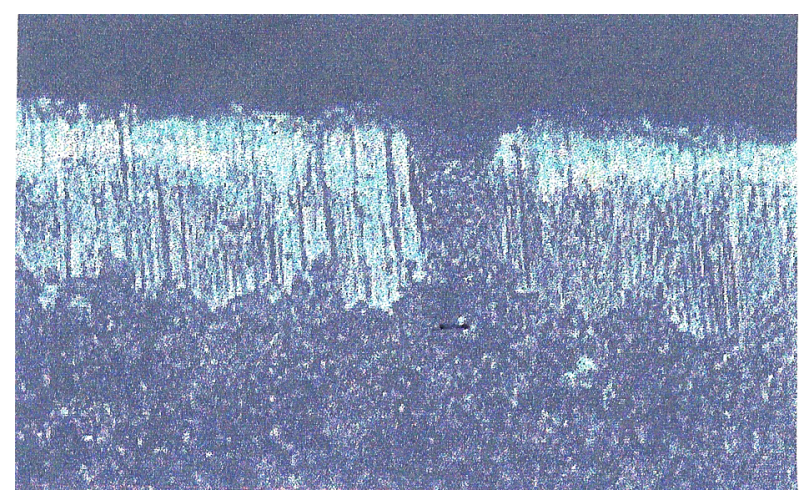

Figure 6. Flank wear on untreated carbide tip after 2535 seconds of turning.

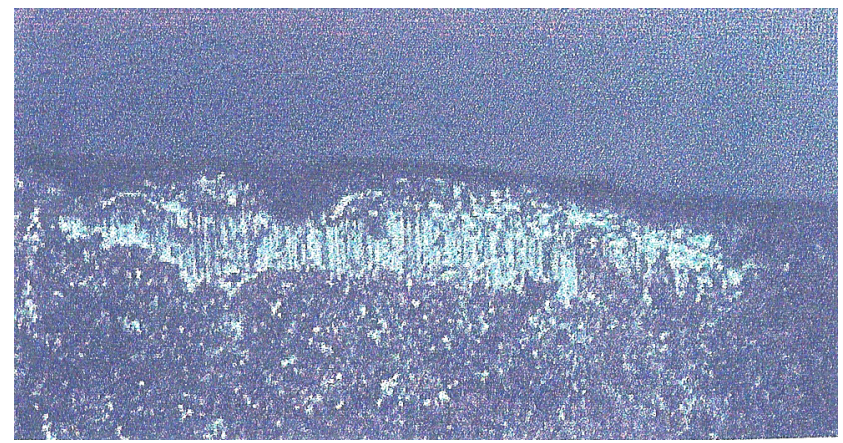

Figure 7. Flank wear on treated carbide tip after 2535 seconds of turning.

\section{Dynamometer tests}

Figures 8. and 9. show the comparison for Dynamometer results for High Speed Steel in the treated(micro blasted) and untreated states with relevant comments.

Similar profiles are shown for coated and uncoated turning tips in both the treated (micro blasted) and untreated conditions in Figures 10. to 13.

In all cases, the micro blasted tips provided an increase in cutting tip life with lower cutting forces recorded. 


\begin{tabular}{|c|c|c|c|c|c|l|}
\hline cut & dynamometer & Rpm & Depth of Cut & Cutting Time & Comments & \\
\hline & microns & & $\mathrm{mm}$ & Seconds & & \\
\hline 1 & 0.071 & 198 & $2 \times 750$ & 642 & & \\
\hline 2 & 0.071 & 204 & $2 \times 750$ & 1284 & & \\
\hline 3 & 0.071 & 208 & $2 \times 750$ & 1926 & & \\
\hline 4 & 0.073 & 212 & $2 \times 750$ & 2568 & Finish Good & \\
\hline 5 & 0.076 & 216 & $2 \times 750$ & 3210 & Deterioration & \\
\hline 6 & 0.079 & 220 & $2 \times 750$ & 3852 & $\begin{array}{c}\text { Built ud edge failing } \\
\text { Tip Failure }\end{array}$ \\
\hline
\end{tabular}

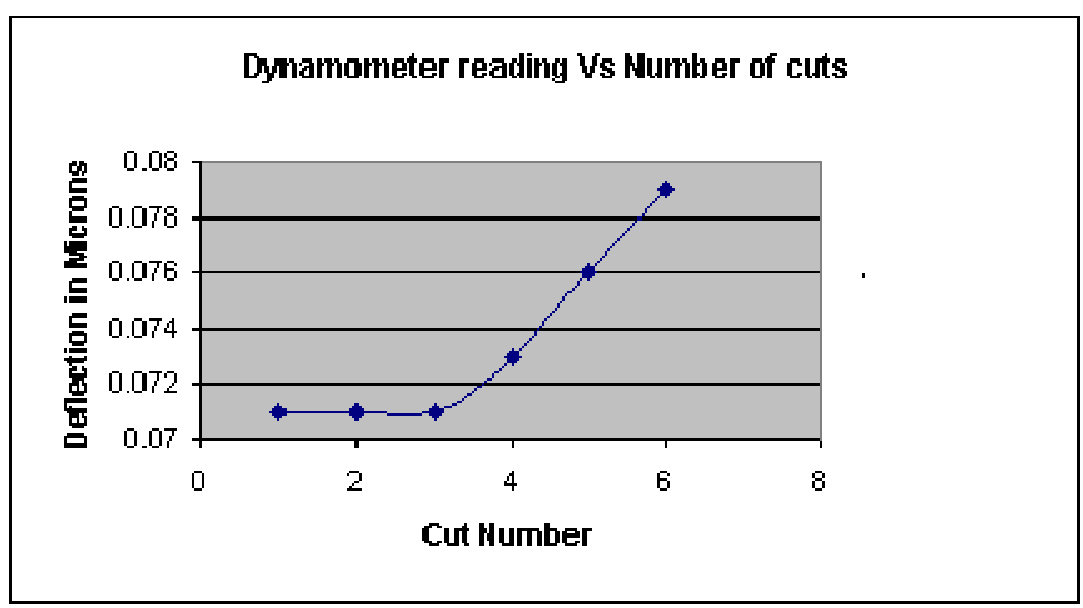

Figure 8. Dynamometer results for micro blasted HSS

\begin{tabular}{|c|c|l|l|l|l|l|}
\hline Cut & Dynamometer & Rpm & Depth of Cut & Cutting Time & Comments & \\
\hline no & (Microns) & & $(\mathrm{mm})$ & (Seconds) & & \\
\hline 1 & 0.074 & 198 & $2 \times 750$ & 642 & & \\
\hline 2 & 0.074 & 204 & $2 \times 750$ & 1284 & & \\
\hline 3 & 0.076 & 208 & $2 \times 750$ & 1926 & cutting edge failing & \\
\hline 4 & 0.081 & 212 & $2 \times 750$ & 2568 & built up edge & \\
\hline & & & & & tip failure & \\
\hline
\end{tabular}

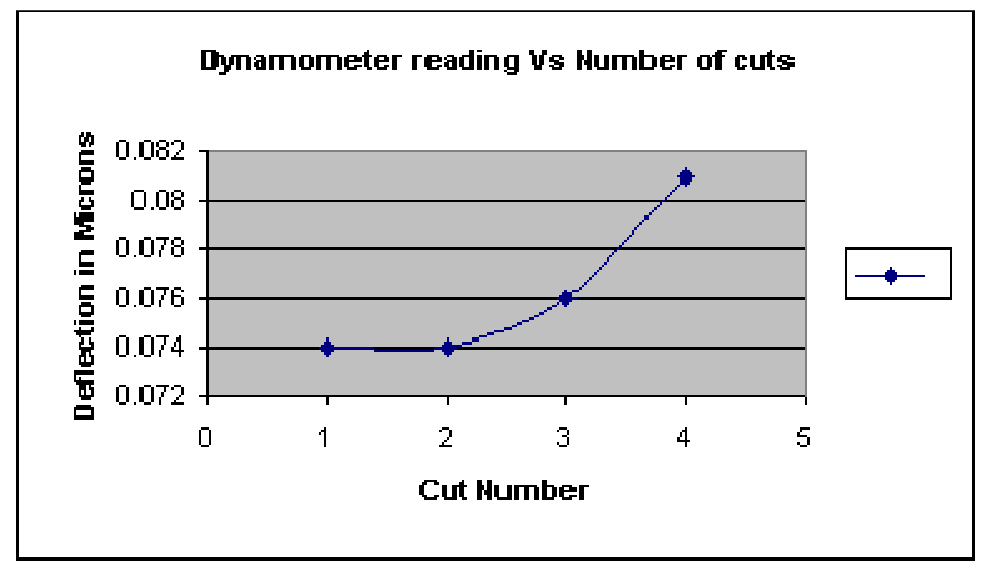

Figure 9. Dynamometer readings for untreated HSS 


\begin{tabular}{|c|c|c|c|c|c|l|}
\hline cut & dynamometer & rpm & Depth of Cut & Cutting Time & Comments & \\
\hline & microns & & $\mathrm{mm}$ & Seconds & & \\
\hline 1 & 0.076 & 1061 & $2 \times 750$ & 169 & & \\
\hline 2 & 0.076 & 1091 & $2 \times 750$ & 338 & & \\
\hline 3 & 0.076 & 1121 & $2 \times 750$ & 507 & & \\
\hline 4 & 0.076 & 1151 & $2 \times 750$ & 676 & & \\
\hline 5 & 0.076 & 1181 & $2 \times 750$ & 845 & & \\
\hline 6 & 0.079 & 1211 & $2 \times 750$ & 1014 & & \\
7 & 0.079 & 1241 & $2 \times 750$ & 1183 & \\
8 & 0.079 & 1271 & $2 \times 750$ & 1352 & & \\
9 & 0.079 & 1301 & $2 \times 750$ & 1521 & & \\
10 & 0.081 & 1331 & $2 \times 750$ & 1690 & & \\
11 & 0.081 & 1361 & $2 \times 750$ & 1859 & & \\
12 & 0.081 & 1391 & $2 \times 750$ & 2028 & \\
13 & 0.081 & 1421 & $2 \times 750$ & 2197 & built up edge failing \\
14 & 0.084 & 1451 & $2 \times 750$ & 2366 & tip at end of life \\
15 & 0.086 & 1481 & $2 \times 750$ & 2535 & tip failure & \\
\end{tabular}

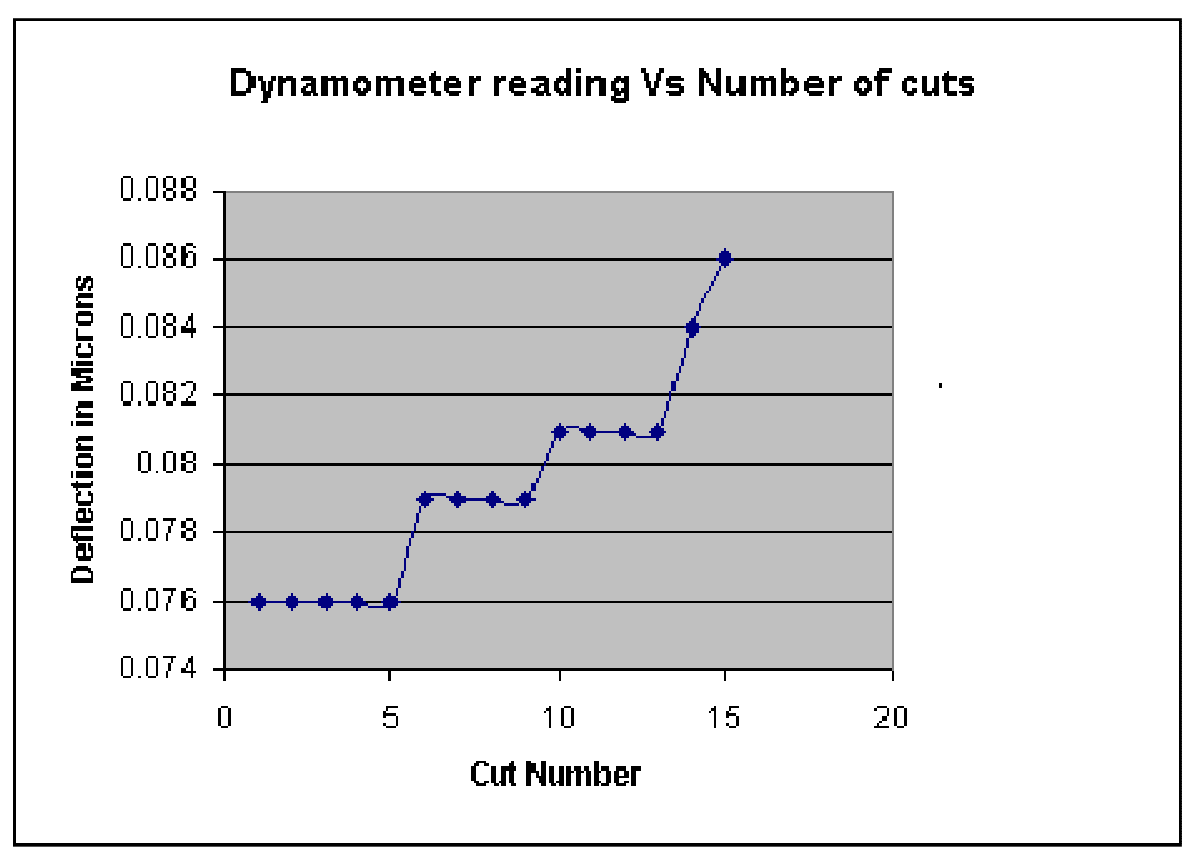

Figure 10. Dynamometer Results for micro blasted coated carbide tip. 


\begin{tabular}{|c|c|c|c|c|c|c|}
\hline cut & dynamometer & rpm & Depth of Cut & Cutting Time & Comments & \\
\hline & microns & & $\mathrm{mm}$ & Seconds & & \\
\hline 1 & 0.083 & 1061 & $2 \times 750$ & 169 & & \\
\hline 2 & 0.083 & 1091 & $2 \times 750$ & 338 & & \\
\hline 3 & 0.083 & 1121 & $2 \times 750$ & 507 & & \\
\hline 4 & 0.083 & 1151 & $2 \times 750$ & 676 & & \\
\hline 5 & 0.083 & 1181 & $2 \times 750$ & 845 & & \\
\hline 6 & 0.083 & 1211 & $2 \times 750$ & 1014 & & \\
7 & 0.083 & 1241 & $2 \times 750$ & 1183 & sparks from tip \\
8 & 0.084 & 1271 & $2 \times 750$ & 1352 & built up edge failing \\
9 & 0.086 & 1301 & $2 \times 750$ & 1521 & tip at end of life \\
10 & 0.086 & 1331 & $2 \times 750$ & 1690 & \\
11 & 0.089 & 1361 & $2 \times 750$ & 1859 & \\
12 & 0.089 & 1391 & $2 \times 750$ & 2028 & \\
13 & 0.091 & 1421 & $2 \times 750$ & 2197 & \\
14 & 0.095 & 1451 & $2 \times 750$ & 2366 & & \\
15 & 0.096 & 1481 & $2 \times 750$ & 2535 & tip failing rapidly \\
\end{tabular}

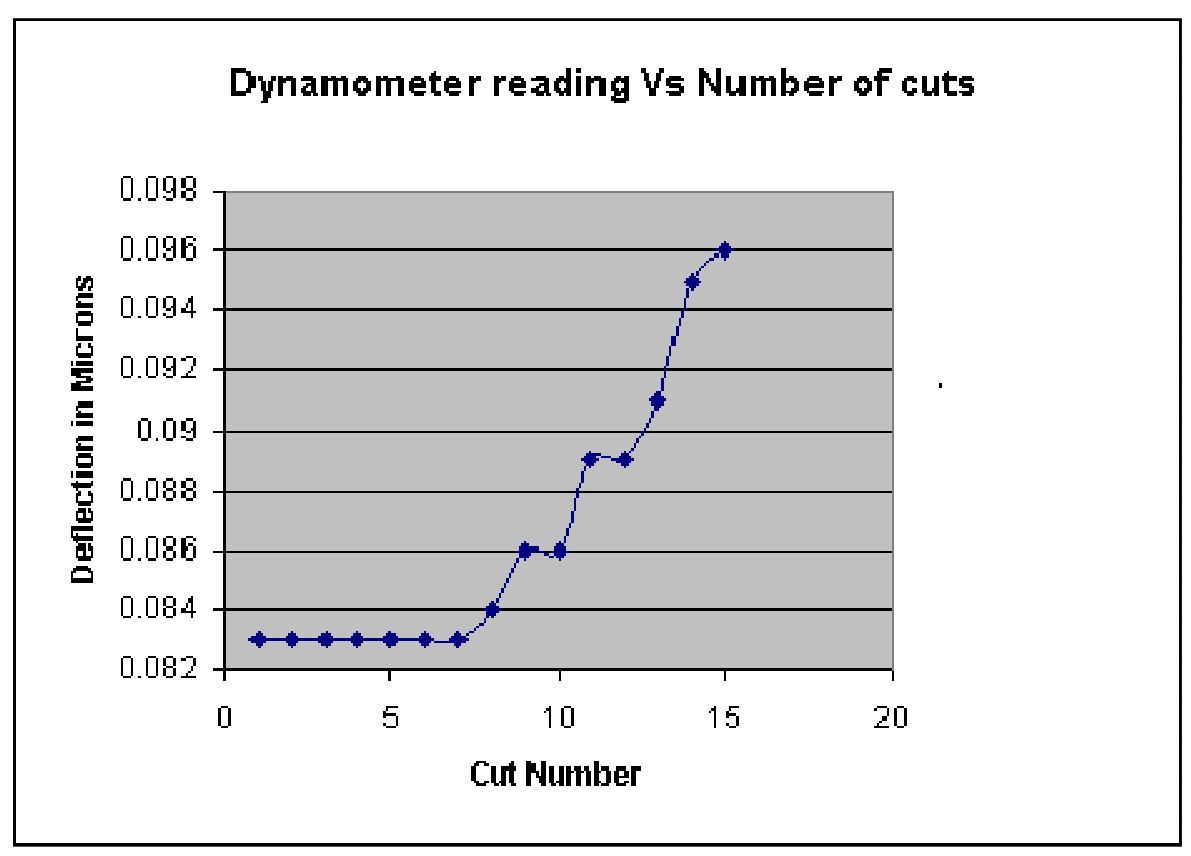

Figure 11. Dynamometer readings for untreated coated carbide tip 


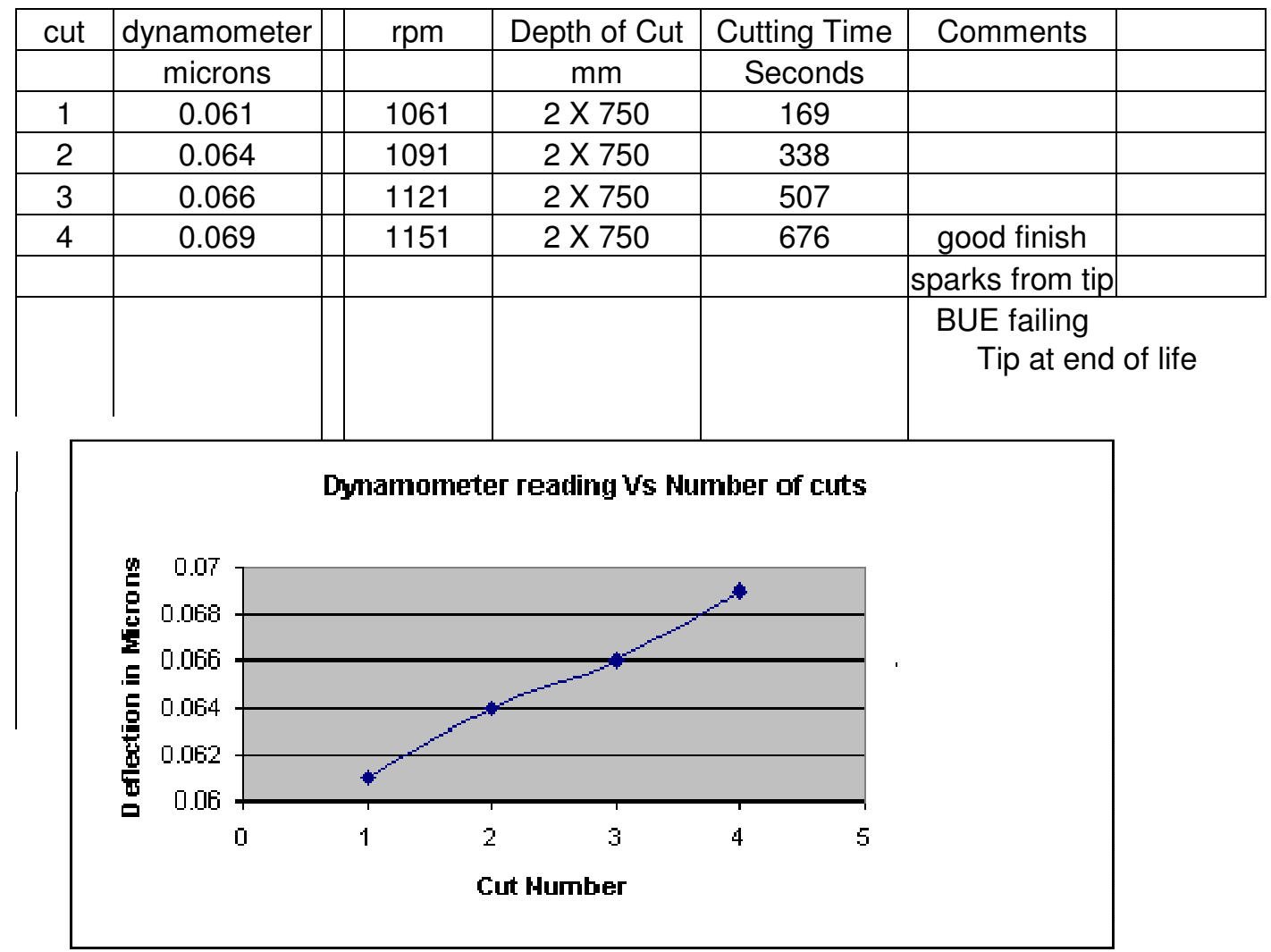

Figure 12. Dynamometer results for micro blasted uncoated carbide tip.

\begin{tabular}{|c|c|c|c|c|c|c|}
\hline cut & dynamometer & rpm & Depth of Cut & Cutting Time & Comments & \\
\hline & microns & & $\mathrm{mm}$ & Seconds & & \\
\hline 1 & 0.069 & 1061 & $2 \times 750$ & 169 & & \\
\hline 2 & 0.071 & 1091 & $2 \times 750$ & 338 & & \\
\hline 3 & 0.074 & 1121 & $2 \times 750$ & 507 & sparks from tip & \\
\hline & & & & & BUE failing & \\
\hline & & & & & & \\
& & & & & & \\
\hline
\end{tabular}

Figure 13. Dynamometer results for untreated uncoated carbide tip. 


\section{Conclusions}

This research work has shown that micro shot blasting of cutting tips and tools has a very positive effect on surfaces by increasing toughness, operating life, improving hardness and surface finish. From the tests conducted, it is obvious that the process effects the residual stresses at or near the surface in a beneficial way by inducing compressive stresses on the substrates tested. The micro blasting process is very simple to apply and economical to use. The mechanical properties of the substrates will determine the type of treatment, i.e. shot hardness, velocity and duration of application in order to obtain maximum benefits from this process. In some cases, authors have reported a 4 to 10 fold improvement in fatigue life in a range of dynamic machine parts subjected to standard shot blasting. Further testing will need to be conducted at the micro shot blasting stage to obtain similar benefits. Other applications for the micro blasting process are currently been investigated by this team and rubber based products that are subjected to fatigue wear are been tested in order to remove the surface voids that produce stress concentrations areas in these materials.

\section{References}

[1] "Impact, Fall 1989, Metal Improvement Company, Bloomfield, Connecticut.

[2] F.P. Zimmerli, Heat Treating, Setting and Shot-Peening of Mechanical Springs", Metal Process, June 1952.

[3] J.S. Eckersley \& Buzz Ferrelli, Using Shot Peeing to multiply the Life of Compressor Components, The Shot Peener, International Newsletter for Shot Peening-Surface Finishing Industry, Volum 9, Issue 1, March 1995.

[4] "J.O. Almen on Shot Blasting", J.C. Alme, General Motors Test, U.S. Patent $2,350,440$.

[5] Jack Champaigne, “controlled Shot Peening”, Elec Inc. 1989, Report. 